\title{
Author Correction: Natural killer cells and other innate lymphoid cells in cancer
}

Laura Chiossone (D), Pierre-Yves Dumas (1), Margaux Vienne and Eric Vivier(D)

Nature Reviews Immunology (2018) https://doi.org/10.1038/s41577-018-0061-z

Published online 12 September 2018

In Box 1 in the originally published version of this article, three key references referring to mouse and human killer inhibitory receptors were mistakenly deleted during revision of the article. These references have now been added to the corrected version of the article.

https://doi.org/10.1038/s41577-018-0077-4 I Published online 12 October 2018

\section{Publisher Correction: Studying tissue macrophages in vitro: are iPSC-derived cells the answer?}

Christopher Z. W. Lee, Tatsuya Kozaki and Florent Ginhoux (D)

Nature Reviews Immunology (2018) https://doi.org/10.1038/s41577-018-0054-y

Published online 23 August 2018

In the original Figure 1, an arrow was mistakenly added between the fetal liver monocytes and the short-term and long-term HSCs. This arrow has now been removed.

https://doi.org/10.1038/s41577-018-0060-0 I Published online 30 August 2018

\section{Publisher Correction: T cells under starter's orders}

\section{Kirsty Minton}

Nature Reviews Immunology (2018) https://doi.org/10.1038/s41577-018-0067-6

Published online 11 September 2018

In the 5th paragraph of the originally published version of this Highlight article, it was incorrectly stated that AMPK is activated by "a high ATP to AMP ratio"; this has now been corrected to "a high AMP to ATP ratio" in the HTML and PDF versions.

https://doi.org/10.1038/s41577-018-0074-7 I Published online 9 October 2018 